\title{
THE MEANING BEHIND ACCRUAL ACCOUNTING AT A LOCAL GOVERNMENT IN INDONESIA
}

\author{
Yudi Y.*, Sudarma M., Djamhuri A., Baridwan Z. \\ University of Brawijaya, Malang, Indonesia \\ *E-mail: yudi.telanai@gmail.com
}

\begin{abstract}
This interpretive study was aimed to reveal the meaning behind the implementation process of accrual accounting at the government of Jambi City, Indonesia. Data were analyzed with Social Construction Theory suggested by Berger and Luckmann. The study found that the implementation of accrual accounting at the government of Jambi City involves two phases. The first phase is preparation, consisting of activities to prepare human resource, to build the application system of financial accounting, and to modify organizational structure. The second phase is execution, comprising activities to implement the application of SIPKD. Analysis toward the phases with regard to the Social Construction Theory on the implementation process of accrual accounting reveales that the meaning behind accrual accounting is reduction of technical and social role played by government accountant in the job of government accounting at Jambi City.
\end{abstract}

\section{KEY WORDS}

Interpretive study, accrual accounting, social construction theory.

The existence of New Public Management (NPM) has long influenced financial management reform in public sector for the sake of establishing more efficient, effective, and accountable public sector (Hood, 1995). The initial step of the NPM for public organization is by embracing government accounting reform (Christiaens, 2001; Christiaens \& Peteghem, 2007). The reform demands the implementation of accrual accounting in order to well run the performance management system of the government (Paulsson, 2006). For three decades, this reform has altered the application of accounting and management systems in African, British, and Greek public sectors (Mimba, Helden \& Tillema, 2007; Chang, 2009; Stamatiadis \& Eriotis, 2011). The same phenomena has also occurred in the last two decades as to accommodate reform in public sector in Indonesia. The reform is carried out by introducing the accrual system as the foundation of the nation accountability (Djamhuri, 2009; Harun, Peursem, \& Eggleton, 2012).

Many researches have been conducted in order to investigate the accrual accounting in Indonesia, such as Prodjohardjono (1999), Djamhuri (2009), and Harun et al. (2012). Prodjohardjono (1999) investigated accrual accounting in various Indonesian local governments with the use of Luder's modified contingency model in order to evaluate how far those governments can successfully apply accrual accounting (see also Luder, 1992; Luder, 2000). Prodjohardjono (1999) eventually revealed that Indonesia was said to not fully successful in conducting accounting reform. Meanwhile, Djamhuri (2009) employed an institutional perspective to investigate the accounting and budgeting reform in certain local governments. In his conclusion, he stated that instant and vast execution of such reform within a short period of time could expect nothing but a shallow institutionalization of the new system.

Other study by Harun et al. (2012), also employing the institutionalization process model in order to evaluate the institutionalization process of accrual accounting in local governments, found out that the process was decoupled. Apart from applying the model, Harun et al. (2012) also used an economic perspective in order to understand the dynamic process of accounting changes within Indonesia's local governments. This perspective viewed that the implementation of financial reporting system among local governments in Indonesia was basically meant to improve the performance of the government organization. 
Nevertheless, this system change was not followed by role distribution between the executives sitting in the governments and the local parliament members (politicians) in making decisions concerning funding and budgeting. This situation was said to be undermining the role of accounting instruments within the decision making process. Thus, it is far from surprising that Harun et al. (2012) eventually concluded that the implementation of the accrual accounting system in Indonesia was nothing but simply following the trend in international accounting that runs NPM agenda.

It is the Organisations for Economic Cooperations Development (OECD) and International Federation of Accountants (IFAC), which supports International Public Sector Accounting Standards Board (IPSASB) to publish International Public Sector Accounting Standard (IPSAS), which initially proposes the accrual-based financial report in public sector (Aggestam-Pontoppidan, 2011). Moreover, Aggestam-Pontopiddan (2011) asserts that IFAC has issued a series of recommendation for the G20 country members to consider during their meeting in June 2010. These actions show that IFAC puts an emphasis to the extent of which the significant element of public sector transparancy is accrual accounting. As a consequence, Indonesia, as one of IFAC country members, has to obey the Statement Membership Obligation (SMO) of IFAC, one statement of which is that all members must use IFRS as their accounting standard.

Athurokala and Reid (2003, p.12-13) reviewed the status of implementation of accrual accounting and budgeting within OECD members. The result of their review shows that most members have come with initial application of aspects of accrual accounting and are likely to continue their implementation in the future. From this result, it can be deprived that the information produced by the accrual accounting system is likely to improve transparancy. However, some other studies managed to show that the relationship between the accrual accounting system and transparancy is somewhat fragile (Carlin, 2005), particularly when dealing with creative accounting or earning management (Jensen, 2001; Mulford \& Comiskey, 2002; Rezaee, 2002; Schilit \& Perler, 2010; Clarke \& Dean, 2014). While scholars are debating whether or not the need of accounting in public sector can be well served by the accrual accounting praxis, there is a significant increase in the adoption of accrual accounting in several public and government entities (Carlin, 2005). This current phenomenon is assumed to be politically influenced by certain global organizations, such as IPSASB, IMF, and World Bank. Though the adoption of accrual accounting is shown to increase, Yamamoto (2001) questioned whether the accounting transformation currently applied by the Japanese government is a revolution or merely fashion. If later found out that it is only a fashion, it can be concluded that the reform is less likely to result in a good government performance.

The kind of financial administration reform on the basis of NPM affects not only technical aspects but also behavioral aspects in a negative manner, such as diminishing values related to public service legitimation, ethics, and motivation (Allison, 1980; Haque, 1999; Manning, 2001). Public officers have turned into rent seekers as they merely attempt to earn as much money as possible in running their public functions according to market mechanism. Within this mechanism, service rate and quality acts as a signal that informs price equality in the market of private goods (Yamamoto, 2001). Indonesia, with its Pancasila (five fundamental pillars of the nation) as the economic platform which embraces gotong royong (communcal work), is supposed not to fully incorporate the market mechanism, rather adopting the NPM approach with particular adjustment to the implementation of performance-based budgeting. Accrual accounting occurs in the budget execution phase. One step of implementing accrual accounting is the establishment of a committee of government accounting standart which is mandated to formulate a guide on budget execution in the form of Government Accounting Standard (according to President's Decree number 84 of 2004, number 2 of 2005, number 3 of 2009, and number 21 of 2013, as well as Government Regulation number 24 of 2005 and number 10 of 2010).

Otley (1980) once warned that not a single accounting system exists that fits with all organizations. The system will constantly change and adjust to organization as it is influenced by several factors, such as organization environment, technology, political policy, 
and structure. To some countries, these factors hinder them from applying the new accounting system. Montesinos and Vela (2013) mention several studies proving that there are obstacles certain countries and governments have suffered from when they are about to implement the technical aspects of accrual accounting, such as Christaens (1999), Ellwood (1999), and Anessi-Pessina and Stecollini (2000). Those parties view that the implementation of accrual accounting is a nonsense idea as it attempts to force business framework into public sector in which both are not similar. As a consequence, the implementation of accrual accounting has turned into irrational and expensive as it needs a great amount of money in order to internalize the system within the public sector. The researchers observed that the development of financial management system by the government of Jambi City, a capital city to Jambi Province, Indonesia, in 2008 needed as much as IDR 200,000,000. If there were 503 local governments in Indonesia, and about 60$70 \%$ of the funding for the accrual accounting system for the entire governments are taken from the national budgeting, then the government has to preserve as much as IDR 65 billions just in 2008.

The budgeting usually is not preserved to the development of the system alone; rather, some amount of money has also to be given to the trainings for operators in order to run the system in each office. Up to recently, the government of Jambi City still depends on outsourced operators for operating the system. If $65 \%$ out of 503 local governments in Indonesia, or about 327 governments, also declare their need of such operators, then each local government has to allow as much as IDR 65 millions. This means the total budget for all participating governments reaches up to IDR 19 billions. This fact illustrates that accrualization of the accounting system is not another job but takes a great deal of money for its implementation. This situation is in accordance with studies carried out by Connolly and Hyndman (2006) and Lapsley, Mussari, and Paulsson (2009) who state that the great deal of money is needed to prepare the accounting resources consisting of technology and its personnels. However, the investment of money, according to Mellett, Macniven, and Marriott (2007), is on the contrary with the expected results as only a little advantage that the governments have experienced.

From the discussion above, it can be seen that Western countries, particularly members of OECD, despite critiques on the implementation of accrual accounting, are moving on with the policy (Paulsson, 2006). The implementation of accrual accounting in Western countries such as France, UK, and the US is considered successful and effective. However, similar result cannot be yielded in the context of developing countries such as Cambodia (Allen, 2009) as there are less capable human resources compared to the ones in Western countries. The active participation in implementing accrual accounting of a country like Cambodia shows that there is a great influence from external parties, i.e. international community, and it proves that external legitimation is not suitable when forced to run in the internal operating system of the country.

Similar to the case of Cambodia and other developing countries, obstacles on implementation of accrual accounting in Indonesia are inevitable. Challenges rise from, among others, organizational changes, structure of accountability, and accounting rules and scheme. This ensures the researchers that the implementation of accrual accounting in the government of Jambi City must be faced with similar challenges, be it technical or nontechnical. One example of technical challenge is the execution of the new rules, while examples of non-technical one are organizational culture and individual behavior which can be sociologically analyzed as both are related with daily life (Berger and Luckmann (1991, p.33) call it as the knowledge that guide behaviors on a day-to-day basis).

The change of rule from Government Rule number 24 of 2005 to number 71 of 2010 as the basis of implementation of accrual accounting certainly affects and is affected by organizational system of the local government of Jambi City. The researchers believe that forcing an implementation process through the instrument of government rule is not productive considering the current, changing development. This act will turn the rule as an absolute postulate that force everyone to execute the rule in whatsoever. 
Organizational culture will affect changes in the structure and composition of an organization, while at the same time both are keys in the implementation of accrual accounting. Civil servants working for the government of Jambi City hold the central role of running the accrual-based accounting. They, as part of an organizational structure with distinguished organizational culture, will be inevitably influenced by such changes. Therefore, the researchers employ interpretive strategy and social construction theory in order to investigate the meaning of the implementation process of accrual accounting in Jambi City.

\section{METHODS OF RESEARCH}

The study was conducted in the local government of Jambi City. The informants, all of which were civil servants working for the government, particularly in Dinas Pengelolaan Keuangan dan Aset Daerah (Office for Management of Regional Revenue, Finance, and Assets, hence called as DPKAD), were interviewed concerning the accrual accounting. They consisted of one Head of the Office, one Secretary of the Office, 3 Heads of Department (Head of Budgeting Department, Head of Asset Department, and Head of Revenue and Expense Department), 4 Heads of Unit (Head of Accounting Unit, Head of Asset Utilization and Security Unit, Head of Budgeting Unit, and Head of Management of Expense and Cash Unit), and one expert-facilitator of the implementation of accrual accounting within the Office.

The researchers applied the purposive sampling technique and inserted the procedure of snowball sampling (Bungin, 2011, p.108; Creswell, 2015, p.412). This procedure suggested to use the first contacted informant or the first person who met with the researchers. This informant, then, gave a reference toward other informants who could potentially be involved in the study or contributed by giving useful information to the researchers. This procedure is often beneficial to seek and recruit «hidden informants», that is, a group of potential informants whom the researchers hardly find an access to by other sampling strategies (Bungin, 2011, p.108).

In short, the procedure of data collection according to Creswell $(2007, p .118)$ is as follow. First, the researchers determine the site and criteria of informants having experience on the phenomena being studies. Second, they gain access and begin to approach individuals' potential as informants with regard to the criteria. Third, they attempt to meet with the informants by using the purposive sampling technique. Fourth, they collect primary data (from participant observation, depth interview, and unstructured interview) and secondary data. Fifth, they take note on information gained from the previous step. Sixth, they classify issues and phenomena the informants are experiencing into several categories. Seventh, they record and keep the data taken in the form of interview transcript and any other forms. This is the end of the data collection phase. The next step is to conduct data analysis.

The main focus of this research is to investigate the implementation process of accrual accounting through the experiences of civil servants of the local government of Jambi City who are related with daily accounting jobs. The research unit of analysis lies on the micro objective reality which leads to facts in the form of behavior, action, and social interaction. The researchers take Berger-Luckmann's social construction theory in order to analyze and reveal the meaning of social reality which is formed through the implementation process of accrual accounting. This study belongs to the micro objective study regarding meaningful individual social action (Bungin, 2011, p.35).

Accrual Accounting in the Context of Indonesia and Jambi City. Financial accountability of local government in Indonesia is demonstrated through, among others, financial report. Hoesada $(2016$, p.4) states that among 503 financial reports of local governments in 2009, only 13 of them successful in gaining the Unqualified Opinion. With this achievement, Indonesia is said to be in the «blind spot» position, signalling that the number of financial reports of local governments which managed to achieve the Unqualified Opinion is bigger, reaching $97.41 \%$. In 2009, the central government wired a total of IDR 309 trillions distributed to the local governments. The huge number of percentage of the «blind spot» area indicates that there is a significant doubt to the implementation of accrual accounting in those local governments. In other words, the local governments have not been able to reach the 
standardized criteria and carry out the determined role. This fact is in line with Guthrie's statement (1998) in that most governments merely follow the current trend in international accountability, instead of fulfilling their real needs (see also Ryan, 1999; Saleh \& Pendlebury, 2006; Wynne, 2008).

The government has a responsibility to enforce financial accountability by publishing financial report to its stakeholders. Accountability serves as the basis of financial report by the government motivated by the right of society to know and receive explanation concerning resource collection and use. This concept of accountability is declared by Governmental Accounting Standards Board (1999) through Concepts Statement Number 1 on Objectives of Financial Reporting. The right of society as the user of the financial report is described in Pernyataan Standar Akuntansi Pemerintah (Statement of Government Accounting Standard or PSAP) number 4 on Note on Financial Report, paragraph $35^{\text {th }}$ as follow:

«Financial Report contains information for different users, such as parliament members, creditors, and aparatus. Other important users include distributors, customers, trade organizations, financial analysts, future investors, guarantee providers, statistic experts, economic experts, and rule-making parties.»

It is seen from the PSAP that certain elements within the society acting as the main users of financial report come mainly from business-related persons, such as creditors, aparatus, distributors, customers, trade organizations, financial analysts, and guarantee providers. The domination of business society affects the orientation of public service by the government in that they adapt the report to the needs of such group of people only.

Concerning the enforcement of financial accountability, the government of Jambi City is committed to implement accrual accounting as mandated by Government Rule number 71 of 2010 concerning Government Accounting Standards. With this rule in mind, the basis of accounting is transformed from cash-based to accrual-based. The issue of implementing new accounting basis lies not only on accounting technical issues, including how to record a transaction and display the financial report, but also, more importantly, on how to determine the accounting policy, the accounting treatment for a certain transaction, accounting options, as well as designing or analyzing the current accounting system and organizational structure.

The output of local financial management system and procedure in Jambi City is, one of them, local financial report issued once a year. During the transformation of the accounting system from cash-based to accrual based, the opinion toward the financial report of the local government of Jambi City issued by Badan Pemeriksa Keuangan (Audit Board of the Republic of Indonesia, hence called as BPK) has never achieved the Unqualified Opinion. Some notes were given by BPK regarding Jambi City's financial report back in 2014, including local asset recording and valuing, be it fixed assets or other fixed assets. In general, through Report of Auditing Result on Financial Report of the Local Government of Jambi City in 2014, BPK stated the following issues to improve:

1. The government did not take and record all fixed assets in the form of equipments and machines funded by Operational Support Funding since 2004 until 2014;

2. The government failed to explain the difference in the number of fixed assets and other fixed assets in the Balance Sheet as compared to the number of recorded assets kept by Equipment Unit which covers the entire details of the fixed assets;

3. The available documents and notes did not enable BPK to conduct a standard procedure of auditing in order to gain confidence on the value of fixed asserts and other fixed assets by December 31, 2014.

The BPK report indicates the weakness in the implementation of accrual accounting in Jambi City in terms of asset measurement, recording, and reporting. BPK has yet not concluded the source of the weakness. This report shows that the financial report of the government of Jambi City remains in Hoesada's blind spot (2016, p.4).

The issuance of Government Rule number 71 of 2010 leads to the obligation of each local government across the nation to implement the accrual accounting system as late as 2015. This obligation indicates that even accounting turns out to be a political tool to control people for the sake of efficiency and performance improvement. The implementation of the accounting is meant to ensure that every public officer uses public fund in an efficient and 
effective manner (see also Guthrie, 1998; Ryan, 1999; Saleh \& Pendlebury, 2006). The responsibility as well as efficiency and effectiveness belong to dimensions of public accountability which include legal and honest accountability, managerial accountability, program accountability, policy accountability, and financial accountability.

Guhtrie (1998) and Kelly and Wanna (2004) relate the transformation into accrual accounting with the rhetoric of financial management reform in public sector. The reform apparently affects the development and optimalization of the function of accrual accounting system. This indicates that the rule of accounting is vital to organizational change. In other words, the transformation from cash-based accounting into accrual-based one will cause change in organizational structure, local financial management mechanism, and the government accounting system. This phenomenon is what occurs in Jambi City. Prior to 2006, the financial management in Jambi City leaned on Ministry of Interior's Decree number 29 of 2002 concerning sole assignments and functions within the structure and organization of financial management in Jambi City. The organizational structure comprised five units, namely, Budgeting Unit, Expense and Wage Unit, Treasury Unit, Recording Unit, and Verification Unit. As the rule changed from the decree to Ministry of Interior's Rule number 13 of 2006, the units was reduced into merely four units. The function of Verification Unit is given to each Satuan Kerja Perangkat Daerah (local government work unit or SKPD) as fund user, after previously managed by Satuan Kerja Pengelola Keuangan Daerah (office of local government chief financial officer or SKPKD) (Yudi, 2007).

After that, the government of Jambi City initiated to issue Accounting System and Standards based on Ministry of Interior's Rule number 13 of 2006 Chapter 239 Verse 1 on Local Accounting Policy and Chapter 232 Verse 2 on Local Accounting System in order to improve the performanc of the organization. The guide consists of procedures of formulation, implementation, management and accounting, report, supervision, and responsibility of local finance. This policy is even enforced by Local Financial Management Cycle as declared in the rule. This cycle indicates that accounting system influences the structure and composition of the organization.

The adjustment to structure and composition of the organization is a sign of commitment of the government of Jambi City in implementing accrual-based accounting. Until 2014, Jambi City's local financial management was carried out by Treasury Unit within the government office, supervised by Head of Treasury Department in which the position is equal to Echelon III. However, at the beginning of 2014, the department was merged with the Office of Local Revenue to become the Office for Management of Regional Revenue, Finance, and Assets (DPKAD) with the sole function to manage the local finance of the city.

At the initial step of the study, the researchers find out the the condition of the organization is far from ideal and is run in a normative manner. This might be caused by misplacement of the aparatus within the organizational structure with respect to their role, right, and responsibility, as well as the needed competences for a certain position. For instance, in DPKAD, Accounting and Report Department is filled by those with Government Science background, Report Unit by those with Engineering background, Asset Utilization, Management, and Security by those with Law background, and Asset Elimination Unit by those with Social Science background. Though believing that incongruent academic background is not a sole guarantee of the success of execution of assignments and functions, we are sure that putting the right man in the right place on the basis of his/her academic background will lead to a more effective resource management. This condition attracts our attention in order to learn individual's experience when confronted with the various jobs of implementing accrual accounting which are different with his/her academic background.

Theoretical Framework. We employed Berger and Luckmann's Social Construction Theory in order to analyze the accrual accounting in Jambi City. Berger sees intersubjective phenomenon from the view of both Durkheim's objectivity and Weber's subjectivity. Durkheim views the existence of subjectivity and objectivity by putting objectivity above subjectivity. On the contrary, Weber believes that subjectivity should be above objectivity. Working at the intersection between the two views, Berger and Luckmann believes that both 
subjectivity and objectivity exists in man's life. Frankly speaking, Berger wants to cojoin together the holistic and individualistic analyzes (Basrowi \& Soenyono, 2004, p.71).

Berger, then, works along with Luckmann to develop his analysis on the basis of reality and knowledge through social construction theory on reality (Berger \& Luckmann, 1991, p.13). They illustrate social process through actions and interactions where individuals constantly and subjectively create their own reality and experience as well as live inside the reality. Reality, they state, is defined as a quality attached to certain phenomena as it occurs beyond man's expectation. Reality here is described as social facts with several attributes, such as external, general, and powerful to force individual awareness. Meanwhile, knowledge is a belief that a certain phenomena is real and possess certain attributes (Berger \& Luckmann, 2013, p.1). In other words, knowledge is a reflection of reality which appears within an individual's conscious mind so that it is said as subjective.

However, the question is: how come a subjective meaning will turn into the objective one? (Berger \& Luckmann, 2013, p.26). This question arises as doubt concerning reality and knowledge that ordinary people have appears. Berger and Luckmann assert that to understand a unique reality from the society adequately, one has to reveal the process of how the particular reality comes into existence by linking the current social condition with reality and knowledge. The dialectic reasoning ability is the ultimate empirical requirement for phenomologists to synthesize contradictive and paradoxical social signs into a more systematic, scientific, and reassuring interpretation (Basrowi \& Soenyono, 2004, p.71). Contradiction and paradox are social realities in the form of man's action taken more as dual reality than single reality.

Even the most individual action ever performed is actually not something new when the action is performed over time (Bungin, 2011, p.39). Man tends to repeat his/her last action. This kind of action considers certain advantages in terms of its efficiency or effectiveness. What comes next within individual life is simply a habitual action. Further, Bungin (2011, p.39) explains that this habitual action is then developed, brought out to the world, and hypothesized in a relationship with other individuals. This type of process develops into a social action which is called as typification. This concept serves as the basis of the existence of the Social Construction Theory over reality in which Berger and Luckmann managed to view that man's action is the reflection of institutionalization process based on dialectic processes: externalization, objectivation, and internalization (see Brouwer, 1984, p.159; Basrowi \& Soenyono, 2004, p.72). Externalization is defined as individual's adjustment process to the socio-cultural world as the product of man. This adjustment is a process where any action performed by an individual will affect the surrounding society. Thus, it is said as "the moment» for an individual to gradually change the pattern of socio-objective world, a process for every unsocialized man to fully take part in forming a new reality (Poloma, 2004).

Objectification belongs to a social interaction in the intersubjective world which is institutionalized. This interaction consists of a process which an individual objectively runs along with its existence within the society. Thus, it is said as «the moment» of reality creation which limits the socio-objective reality (Poloma, 2004). Internalization is defined as a process by an individual when he/she is attempting to self-identify him/herself with social institutions where he/she belongs. This individual action is greatly influenced by the circumstances of the surrounding society (Basrowi \& Soenyono, 2004, p.72; Fatchan, 2013, p.27-28). This process is «the moment» of reality creation where the socialization occurs (Poloma, 2004).

Kuswarno (2009, p.21) asserts that Berger and Luckmann's Social Construction Theory attempts to establish dialectic between an individual and his/her environment in dealing with social phenomena involving interactions between the individual and his/her world. In other words, according to Berger and Luckmann, man's actions are dialectic between him/herself and the socio-cultural world. Therefore, the social construction theory can be used as a descriptive and empiric method as it is based on man's experience. This theory is useful to analyze social reality which forms knowledge from social interactions. In the meantime, social reality in daily life itself comes from inter-actor interactions in order to establish a certain system and structure. This way, social reality will be well and fully 
understood. A deep understanding on organizational social reality is vital, bearing in mind this knowledge is excerpted directly from the real world which, in turn, will become the "raw material» in formulating practical concepts (Triyuwono \& Roekhuddin, 2000, p.154).

\section{FINDINGS AND DISCUSSION}

Some informants think that the implementation of accrual accounting is inevitable for aparatus working in Indonesia's local governments. Their opinions are a form of explicit awareness or values arisen from their experience when dealing with accrual accounting in their organization. In the end, this experience turns into a deeper awareness that accrual accounting is an obligation the local governments must take into account as the central government has declared them to do so despite their low understanding on what is the beneficial of such accounting. In other words, we find that aparatus understanding is at the level of first order in that they view accrual accounting as an obligation.

The implementation process of accrual accounting in the local government of Jambi City consisted of two phases, namely, preparation and execution. Some obstacles are found out during the two phases, such as (1) low quantity and quality of human resources regarding accrual accounting, and (2) failure to adapt with accrual accounting which demands on-time transaction rather than delayed accomplishment as aparatus tended to do with the old system. Several activities were carried out at the first phase of the implementation, including preparing human resources as the operators of accrual accounting, establishing local financial management system, and adjusting the organizational structure.

In preparing the human resources, four-day socialization was held and delivered by a speaker recently attended a Training for Trainers (ToT) on accrual accounting at Jakarta, the capital city of Indonesia. With inadequate knowledge on accrual accounting, he seemed to enforce himself to deliver the materials to all accounting operators from all SKPD. Not only delivering materials on accrual accounting, the socialization also trained the attendees on how to form the SIPKD application by facilitating consultants. It is this application that will hold an important role when dealing with accrual accounting in the government of Jambi City.

The establishment of an application for local financial management system has already been initiated prior to accrual accounting. Thus, this application was adjusted to the use of accrual accounting according to the rule of local financial management. This application is one solution to overcome the low quantity and quality of knowledge suffered by the aparatus concerning accrual accounting. The government of Jambi City worked together with a few parties to develop the application and facilitate consultation for the aparatus. However, until the end of the facilitating period, some issues remained problems for the aparatus to run accounting transaction. The government, then, decided to assign one member of the consultant team as a part-time employee in order to assist other aparatus in running the application.

Changing the organizational structure of the government was not only meant to accommodate the implementation of accrual accounting, but also to accommodate its needs concerning improvement on performance effectiveness. The function of accounting became an important part of the change with Budgeting and Spending Need Analysis Department becoming the «leader» in implementing accrual accounting in Jambi City. This was because the department had several aparatus with excellent competences on accounting and computer application. These aparatus had always kept in touch with latest development of financial management since DPKAD was not formed and the government had not implemented accrual accounting.

The second phase was the execution of the SIPKD application. The low understanding of the human resources on accrual accounting could be covered by the use of this application. The only disadvantage was that the aparatus greatly depended on the sophisticated application. The weakness of the aparatus had been solved with the use of the application in solving accrual accounting issues, including fixing transaction errors without exploring features in the application. This was caused by the aparatus who less understood 
accounting-based work and kept their bad habit of delaying accomplishment of a job as well as made errors during transaction, including mistyping date of transaction, registration number, and value of transaction. The aparatus usually turned to the administrator of the application to fix their issues through the database system. As a consequence, the recorded transaction via the application looked like perfect, not experiencing any errors.

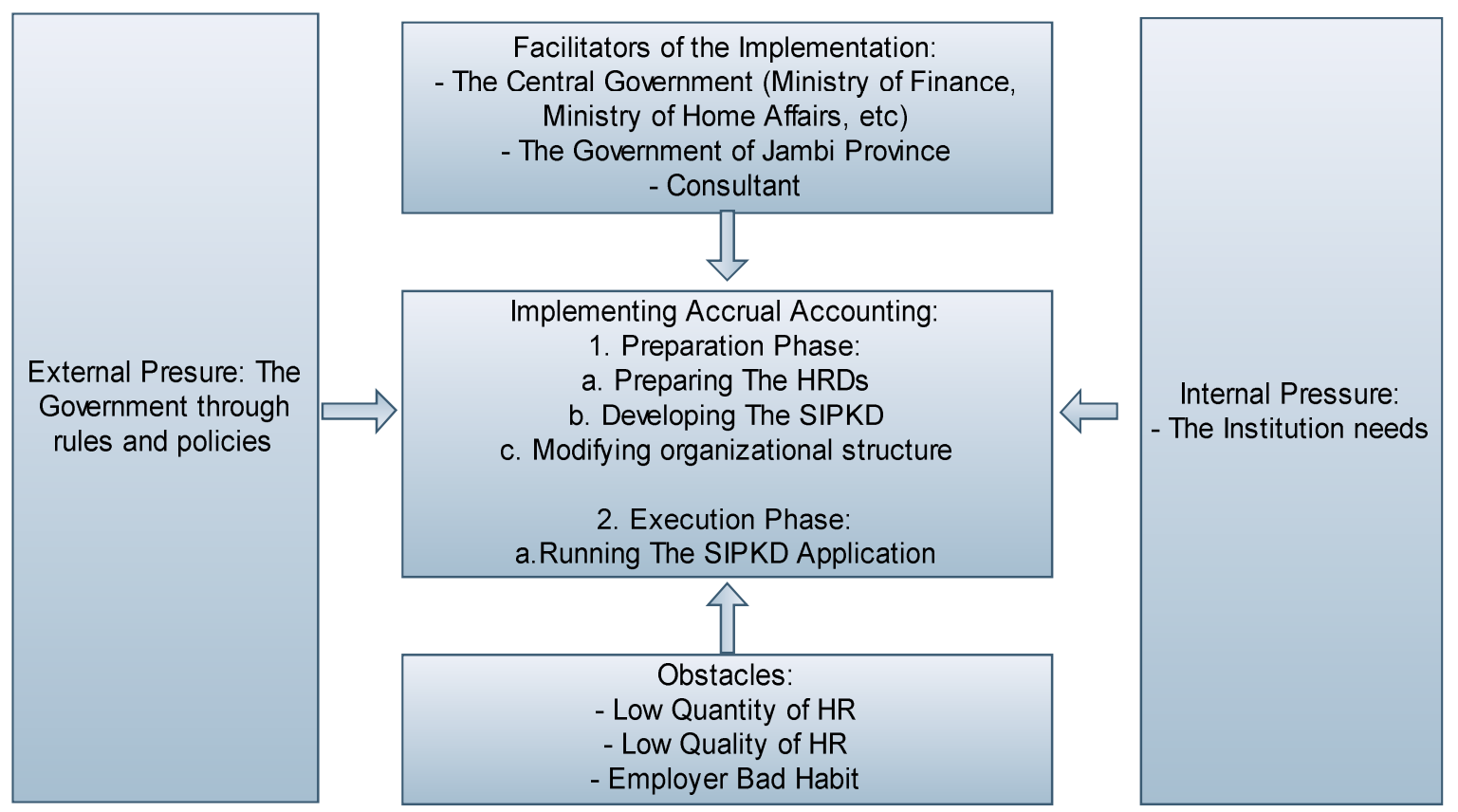

Figure 1 - Model of Implementation Process of Accrual Accounting in the Government of Jambi City

We also find that there is an employee from a certain SKPD, whose main job is to collect regional taxes and regional retribution, does not have adequate technical knowledge on how to analyze aging of account receivables and determine percentage of allowance for bad debts in her office. She is also obliged to write report on allowance for bad debts, including tax arrears and retribution arrears. Nevertheless, this employee is dedicated to perform his job and is willing to learn from others who have better knowledge on account receivables, particularly, and accrual accounting, generally.

Defining Social Reality of Accrual Accounting. The Social Construction Theory views the three moments of social phenomenon process through assumption that there exists socio-objective reality found in the relationship between individuals and social institutions. An example of big-scaled social institution is nation. Social rules or laws which base the existence of a nation create the attribute of coersive as a consequence of man's activities during the externalization process or during man's interaction with existing social structures. These rules or laws force individuals to perform certain action in order to sustain the existing social structures; yet, it is not always followed by fully-accomplished externalization process of the individuals living in such social structures. The organization is forced to run a new procedure and system. Berger and Luckmann (2013, p.71) believe that externalization is an anthropological obligation. The existence of man requires continuous externalization in various activities which is not possible within closed and narrowed inferior environment.

Externalization Process in Implementing Accrual Accounting. This process occurs in the interaction of aparatus with accrual accounting in the government of Jambi City under the central government policy which obliges the implementation of the accounting to all local governments. This obligation is taken by the lowest-level aparatus or the true executor of the implementation as a rule that they must obey without questioning or knowing the advantages of the accrual accounting itself. In other words, these aparatus' thought and action in the externalization process of accrual accounting belongs to the category of non-confrontative action. 
The aparatus take the rule as it is with regard to their current competence. Despite some technical issues during the implementation, they managed to do their work well. Every obstacle is communicated with their superiors and accounting operators of DPKAD. During the externalization process, these aparatus hold their social role in accordance with their respective job descriptions. Through this role, they adapt themselves with obstacles they are facing. This role also serves as the basis of objective, institutionalized rules. The aparatus attempt to identify their own role under a common goal that is, creating stability within their organization.

The obligation to implement accrual accounting becomes a moment for the aparatus whose work is related local financial management to know, understand, and learn about it. Their different academic backgrounds and culture or work habit lead them to no other way but adapt with accrual accounting social structure. They, then, interpret the rule according to their knowledge obtained from attending socialization and trainings as well as getting themselves in touch with the new system. Their good understanding on accrual accounting enables them to manage the entire operational actitivies related to accrual accounting. It is this good understanding that forces them to adapt with the demand and to construct their knowledge concerning accrual accounting.

Beside influenced by the rule of accrual accounting implementation, the aparatus' understanding is also affected by the implementation of such accounting in the other institutions. Ms. E is known as a DPKAD employee who becomes the first place to get any reference regarding technical aspects of accrual accounting implementation. Her knowledge and understanding on accrual accounting was obtained from trainings she once attended at Indonesia's Ministry of Interior and the government of Jambi Province. These two institutions act as the main source of knowledge when it comes to talk about accrual accounting. The government of Jambi City has never even conducted a complete cost and benefit analysis regarding the implementation of accrual accounting. The aparatus working in the heart of the government of Jambi City simply believe that the rule determined by the central government and the government of the province must be best for their government in particular and the nation in general. Not only the two institutions but also consultants of the SIPKD application have a significant influence on the implementation of accrual accounting. The influence of the latter party was so great that the government of Jambi City decided to take one member of the consulting team as a part-time employee with the sole task and function to carry out supervision on the implementation of accrual accounting.

The environmental circumstances influence the aparatus understanding and their adaptation process. Several mentioned circumstances include (1) low quantity and quality of human resources related to technical as well as general understanding and knowledge on accrual accounting and (2) the aparatus procrastinating habit. The procrastinating habit is paradoxical to the spirit of accrual accounting which demands on-time accomplishment of transaction. The first obstacle is related to lack of human resources with accounting academic background. Quantitatively and qualitatively speaking, there is only one civil servant employee with accounting academic background, that is, Mr. E. The other person is the part-time employee recruited from the SIPKD application consultant team. We find an interesting phenomenon related to the non-accounting academic backrground of this employee which significantly affects the implementation of accrual accounting. Mr. E earned a Sarjana's (four-year undergraduate) degree in Computer Engineering. She has become a vita part in the implementation of accrual accounting. Her jobd is to operationalize the SIPKD application. As time goes by, she eventually learns and gets used to accrual accounting. Her understanding and knowledge was obtained from learning the accrual-accounting-related rules when she was developing the SIPKD application. We also find some other aparatus working with accounting coming from various academic backgrounds, such as Diploma in Health Affairs and Sarjana's degree in Agriculture. This social reality will influence how the aparatus respond to the implementation of accrual accounting.

The government of Jambi City has been fully aware that the low quantity and quality of human resources, technology, and facilities are issues to resolve so that the implementation of accrual accounting will smoothly run. One of the attempts is by conducting a comparative 
study with other institutions, that is, the government of Depok City and Jambi Province in order to learn how the two institutions implement accrual accounting within their organizations. The government of Jambi City needs an accurate reference concerning solutions to take. However, this attempt fails to provide reference for the government to implement accrual accounting. Therefore, the government looks for various other ways to increase the quantity of human resources.

One other attempt is by recruiting a part-time employee from the SIPKD application consulting team. This recruitment aims to transfer the knowledge regarding accrual accounting from the newly recruited employee to the aparatus whose work is related with accounting. Moreover, several traing and socialization programs are also held periodically in order to improve their technical understanding on accrual accounting. At this moment, we find that there are aparatus who often make mistakes during taking notes of expense and income accounting transaction and during reporting regional tax arrears and regional retribution arrears.

Objectivation Process of Accrual Accounting Implementation. The aparatus' daily reality in facing with accrual accounting has enabled them to run their role and function as an «accountant». Accrual accounting turns to be a social reality set within patterns which are less influencing to their understanding on accrual accounting itself. This social reality, in later development, undergoes an objectivation process, meaning that it is formed into certain labelled objects. This reality is then organized around the aparatus, comes into existence in their daily life, and is possibly manipulated by them. The process of objectification enables the aparatus to reach the accrual accounting social reality, the world where they have a freedom to modify their own working environment. Within this world, their conscious mind is dominated by pragmatic motives.

Accrual accounting, then, turns to be their daily reality along with other aparatus; in other words, it turns out to be their intersubjective world. The aparatus' existence toward one another is marked with interaction and communication. The interaction and communication, of course, needs a common language so that everyone share a common understanding in carrying out the reality. The language is interpreted as a system of signs. Its foundation lies on the predetermined rules.

General objectivity from daily life is sustained by language significance (Berger \& Luckmann, 2013, p.50). In order to deliver shared meanings, language requires certain system of signs which will make it more understandable. In this case, one important attribute of objectivation process is man's labelling (Berger \& Luckmann, 2013, p.48). The objective of creating signs is to serve as signs or indexes toward subjective meanings. Labels are grouped into a system in order to mark common subjective meanings. Through the labelling system, subjective meanings will be taken by the aparatus into account in an objective and constant manner. It is through the labelling system, the aparatus' understanding on accrual accounting social reality will improve. This knowledge is socially objectified as knowledge which serves as tools of truth adequately applied as reality. In other words, every deviation of rules will be taken as deviation of reality. The knowledge manifested in the form of SIPKD application acts as the core of fundamental dialectic of the aparatus. The SIPKD application "programs» the social reality of rules and other institution during the process of externalization into an objective world. Knowledge is objectified in the form of SIPKD application through features which act as interface signs and interpret them as objects to be taken as reality.

In the objectification process, the government of Jambi City set rules that demand the aparatus to experience learning process, particularly not on new ways to respond, but new ways to appreciate new situation the institution has created for itself. One of the expected responses is the use of computer as the technological answer for improving the aparatus' capacity in implementing accrual accounting. The government of Jambi City realizes the important of labelling system in order to overcome issues when implementing accrual accounting. The labelling system is shown in the form of SIPKD application developed and established along with a team of consultants. All accrual-accounting-related rules serve as the fundamental of building and developing the SIPKD application which accommodates the 
accrual accounting system. This application is aimed to improve the aparatus' capacity in general regarding the implementation of accrual accounting.

Objectification of accrual accounting in the form of SIPKD application becomes a tool to help the aparatus in accomplishing accrual-accounting-related jobs. These jobs have become their daily life. The application serves as the entrance gate to practical knowledge of accounting and as a language easier to understand and use in carrying out their accountingrelated activities. In other words, even non-accounting aparatus can conduct «any» accounting transaction with the application, including writing a full report of local finance.

The accounting job established with technology, in this case a computer application, has enabled the aparatus to obtain both biographical and historical experiences in a selective way. These experiences will be accumulated and kept in their mind as stored knowledge. Eventually, continuous interaction among the aparatus on a daily basis will influence one another and altogether build stored knowledge in the society. The aparatus and society's knowledge are formed by institutionalized behavior through predetermined rules.

Individual aparatus have their respective obstacles. This is caused by different knowledge and culture in the mind of each aparatus. This situation leads to different capacity, assessment, and competence building for each aparatus in handling, managing, and communicating information related to accrual accounting. It can be said that the objectification process unifies the aparatus' different perspectives in their daily environment. This is because the implementation of accrual accounting has been determined by a set of rules in that all local governments along with its operators must obey. The rules are established in such a way that they do not consider the executors' perspective. However, inter-aparatus dialogues regarding accrual accounting should enable the creation of new meanings which influence the employee's action and views regarding the new system. Therefore, objectification process requires interaction among the aparatus.

Internalization Process of Accrual Accounting Implementation. The aparatus new knowledge undergoes an internalization process to become objective truth which is expected to apply in daily life. All man's activities experience the process of habitualization (Berger \& Luckmann, 2013, p.72). Every repeated action will become a certain pattern that will be reproduced with only small energy as the action has been understood or internalized by the actor. Man's habitual action cannot be separated from his/her available knowledge in mind so that the action can be easily performed. The internalization process take places when the objectified social reality is returned to conscious mind at the time of socialization. During the process, the aparatus' stored knowledge will improve and is forwarded to other aparatus. This reality will create individuals with certain specification, in this case aparatus with capability in accrual accounting. These aparatus will eventually turn into a member of the society with the knowledge of accrual accounting in mind. The existence of the aparatus in the world of accrual accounting will be defined and controlled by this knowledge structure.

The development of SIPKD application in the process of objectification greatly contributes to the implementation of accrual accounting in the government of Jambi City. This technology serves as a great solution to overcome all issues that the government is experiencing. The existing condition is no longer an issue. The internalization process is the attempt to make the aparatus learn and understand the accrual accounting. The process is conducted through a series of socialization and trainings on the use of the SIPKD application. The socialization is useful to teach the aparatus on how to operate the accrual accounting with regard to their background. The aparatus have a vital role in implementing accrual accounting. However, the two strategies employed by the government have not shown their clear success. This information is brought by Mr. $\mathrm{H}$ who thinks that the aparatus attending the socialization do not meet the predetermined qualifications. He thinks that the government needs to come with a strategy to bind the aparatus voluntarily with the new reality. In short, the implementation process of accrual accounting in the perspective of Social Construction Theory can be seen in Figure 2.

Apart from socialization and trainings, the internalization process is also carried out by the aparatus with sufficient skills and knowledge on accrual accounting and the SIPKD application. Mr. E and Ms. E hold an important role during internalization. Their interpretation 
toward the rules, knowledge on accrual accounting, and their ability to operate the SIPKD application serve as the main reference for the other aparatus to run their accounting activities. Eventually, the other aparatus are «encouraged» to conduct their own accrual accounting activities. The internalization process of accrual accounting through the SIPKD application will eventually lead the aparatus to learn "why» accrual accounting is the way it is. The aparatus are able to «implement» accrual accounting as mandated by the rules.

The internalization process is likely to run well with the help of the technology; even some say that it is "excellently» executed. The impact of this implementation is that the aparatus heavily depend on the application to carry our their daily activities. The dependency is vividly seen when the server of the application is damaged due to a problem of the electricity. The aparatus do nothing while the application is off until the office can turn back their electricity on. From this example, it is seen that the aparatus becomes an inevitable part of their life at work. The technology turns out to be their «third hand» in carrying out their activities. Once the application fails to run, the aparatus can do nothing until the issue is resolved. In Ihde's term (see Lim, 2008), the application has «manifested» within the aparatus' soul.

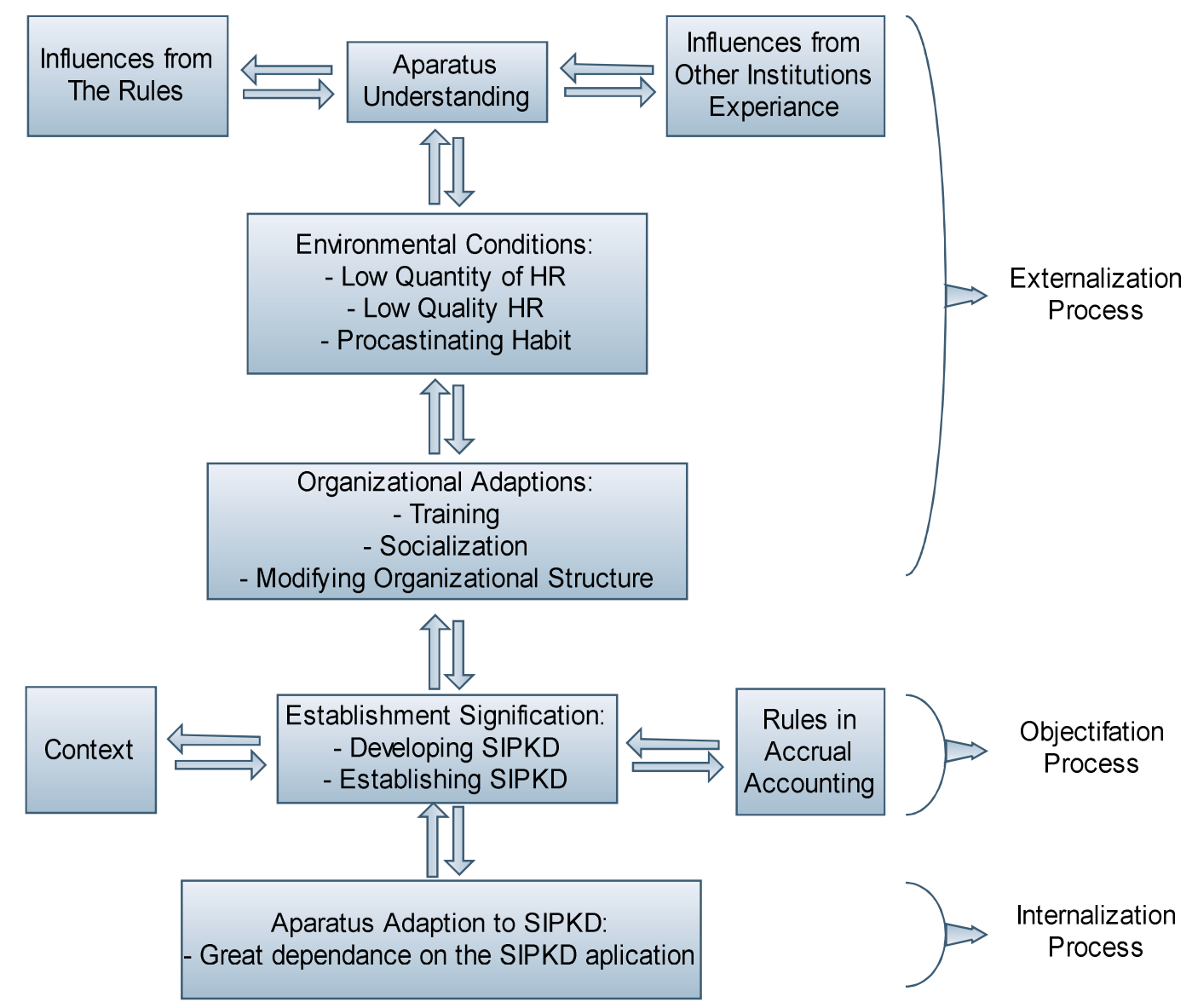

Figure 2 - The Implementation Process of Accrual Accounting in Jambi City from the Perspective of Social Construction Theory

In line with Ihde's view, the materiality of technology becomes a part of the aparatus' body and soul (Lim, 2008, p.102). Tools as media and the world provide a partial experience in the life of man. The application also provides experience to the aparatus in implementing accrual accounting. In the phenomenology framework, the SIPKD application is included in the work intentionality. The aparatus work with the help of the application in order to produce accrual accounting. Noema is the accrual accounting, while noesis is the action of working. The intentionality is shown in the accrual accounting, while the action of working is performed through the SIPKD application. In this case, the application technology is included to perform 
work in a certain manner and leads to perceptional change and change of sense within the aparatus's body. The application is there between the aparatus and accrual accounting, or in the mediating position. The intentionality of working is directed to accrual accounting, while the aparatus work on the basis of accrual accounting through the application.

Working with the application requires intensive learning. When about to operate the SIPKD application, the aparatus are going to need some time to adapt themselves with the available features in the application? Confusion at the beginning of using the application is natual. However, after some time, using the application has become part of their mind and soul. The application has become part of the aparatus when carrying out accrual accounting. In later development, less attention will be given to the SIPKD application itself as the sole focus now is working on the accrual accounting. Thus, the result matters, much more than the features of the application itself which merely serves as a mediator between the aparatus and the accrual accounting. In other words, the application has lived in the aparatus' body and soul. The technology lives together with its users in a humanized action.

The accrual accounting social transformation within the government of Jambi City is somewhat complex and reversive between the process and the daily practice. The accrualbased accounting which initially was a technical terminology enforced by several government's rules and policies has turned into a social reality with vast impact on the social accounting function itself. Sophisticated and complex understanding on the accounting is facilitated by technology to become a common «language» that is widely comprehended by the aparatus. The role of accountant also transforms. A medical expert to computer programmer even can run accounting activities without major problems. An «accountant» does not have to possess "accounting capability" earned from an accounting education program if he/she is merely to record and report accounting transaction in the government office. It is clear that technology holds a significant role in social transformation. The Social Construction Theory views accrual accounting as technical and social reduce of the role played by accountant in the accounting of the government of Jambi City.

\section{CONCLUSION}

The implementation of accrual accounting in the government of Jambi City consists of two phase, namely, preparation and execution. In the preparation phase, some activities are carried out, including preparing the local financial management information system, preparing proper human resources in order to obtain technical knowledge on running accrual accounting, and changing the organizational structure. After that, in the execution phase, the government conducts several activities, including operating the SIPKD application, assessing fixed assets, and calculating debts. During this phase, some obstacles are found, including low quantity and quality of human resources regarding the implementation of accrual accounting and the aparatus' habit to procrastinate when the accrual accounting requires ontime transaction.

We employ Berger and Luckmann's Social Construction Theory in order to analyze the social reality during the implementation of accrual accounting comprising three momentums of process. In the first process, i.e. the externalization process, the aparatus' understanding and interpretation regarding accrual accounting are influenced by the rules and other institutions' experience. Moreover, there is also an impact from the institutional environmental condition, that is, the low quantity and quality of human resources and procrastinating habit. Therefore, the government conducts an organizational-based adaptation to the aparatus by holding trainings and socialization. The institution also conducts a change on the organizational structure in order to adjust with the new set of rules and local financial management system.

Afterwards, in the objectification process, the government of Jambi City develops and establishes an application as knowledge manifested in the form of SIPKD application. The application "programs» social reality of rules and other institutions' experience from the externalization process into an objective world.

During the internalization process, the knowledge learned by the aparatus is re- 
internalized as an objective truth which is continuously carried out. The internalization process creates individuals with specified skills and knowledge, in this case, the aparatus with knowledge on accrual accounting. The encouraged aparatus are able to conduct accrual accounting. However, prior to reaching the "expert» level, the aparatus become greatly dependance on the application. The technology has become an inevitable part of their accounting job. In other words, the application has lived in the aparatus' body and soul. The technology lives together with its users in running the accrual accounting job.

Finally, the study concludes that the implementation of accrual accounting in the government of Jambi City reduces the role of aparatus with accounting academic background as it is gradually replaced by the SIPKD application. In other terms, the meaning of accrual accounting reduces the social role of accountant in the accounting of the government of Jambi City.

\section{REFERENCES}

1. Aggestam-Pontoppidan, C. 2011. Selecting International Standards for Accrual-Based Accounting in The Public Sector: IPSAS or IFRS? The Journal of Government Financial Management, 60 (3), 28-32.

2. Allen, R. 2009. The Challenge of Reforming Budgetary Institutions in Developing Countries. International Monetary Fund.

3. Allison, G. T. 1980, February. Public and Private Management: Are They Fundamentally Alike In All Unimportant Respects? Paper presented at the Public Management Research Conference, Washington, D.C.

4. Athukorala, S. L., dan Reid, B. 2003. Accrual budgeting and accounting in government and its relevance for developing member countries. Asian Development Bank Manila.

5. Basrowi, M., dan Soenyono. 2004. Teori Sosiologi Dalam Tiga Paradigma. Yayasan Kampusina, Surabaya.

6. Berger, P., dan Luckmann, T. 2013. Tafsir Sosial Atas Kenyataan: Risalah Tentang Sosiologi Pengetahuan, (H. Basari, Penerjemah.). LP3ES, Jakarta.

7. Berger, P. L., dan Luckmann, T. 1991. The Social Construction of Reality: A Treatise in The Sociology of Knowledge. Penguin UK.

8. Brouwer, M. A. W. 1984. Psikologi Fenomenologis. PT. Gramedia, Jakarta.

9. Bungin, B. 2011. Metodologi Penelitian Kualitatif: Komunikasi, Ekonomi, Kebijakan Publik, dan IImu Sosial Lainnya. Prenada Media Group, Jakarta.

10. Carlin, T. M. 2005. Debating The Impact of Accrual Accounting and Reporting in The Public Sector. Financial Accountability \& Management, 21 (3), 309-336.

11. Chang, L.-C. 2009. The Impact of Political Interest Upon The Formulation of Performance Measurements: The NHS Star Rating System. Financial Accountability \& Management, 25 (2), 145-165.

12. Christiaens, J. 2001. Converging New Public Management Reforms and Diverging Accounting Practices in Flemish Local Governments. Financial Accountability \& Management, 17 (2), 153-170.

13. Christiaens, J., dan Peteghem, V. V. 2007. Governmental Accounting Reform: Evolution of The Implementation in Flemish Municipalities. Financial Accountability \& Management, 23 (4), 375-399.

14. Clarke, F., dan Dean, G. 2014. Corporate Collapse: Regulatory, Accounting and Ethical Failure. In F. Clarke and G. Dean (Eds.), Accounting and Regulation. hlm. 9-29. Springer.

15. Connolly, C., dan Hyndman, N. 2006. The Actual Implementation of Accruals Accounting: Caveats from A Case within The UK Public Sector. Accounting, Auditing \& Accountability Journal, 19 (2), 272-290.

16. Creswell, J. 2015. Riset Pendidikan: Perencanaan, Pelaksanaan, dan Evaluasi riset Kualitatif dan Kuantitatif. Pustaka Pelajar, Yogyakarta.

17. Creswell, J. W. 2007. Qualitative Inquiry and Research Design: Choosing Among Five Approaches. Sage, London. 
18. Djamhuri, A. 2009. A Case Study of Governmental Accounting and Budgeting Reform at Local Authority in Indonesia: An Institusionalist Perspective. Doctor Philosophy, University Sains Malaysia, Malaysia.

19. Fatchan, A. 2013. Metode Penelitian Kualitatif: 10 Langkah Penelitian Kualitatif Pendekatan Konstruksi dan Fenomenologi. Penerbit Universitas Negeri Malang, Malang.

20. Guthrie, J. 1998. Application of Accrual Accounting in Australian Public Sector: Rhetoric or Reality? Financial Accounting and Management, 14 (1), 1-19.

21. Haque, M. S. 1999. Relationship Between Citizenship and Public Administration: A Reconfiguration. International Review of Administrative Sciences, 65 (3), 309-325.

22. Harun, H., Peursem, K. V., dan Eggleton, I. 2012. Institutionalization of Accrual Accounting in The Indonesian Public Sector. Journal of Accounting \& Organizational Change, 8 (3), 257-285.

23. Hoesada, J. 2016. Bunga Rampai Akuntansi Pemerintahan. Salemba Empat, Jakarta.

24. Hood, C. 1995. The "New Public Management» in The 1980s: Variations on A Theme. Accounting, Organizations and Society, 20 (2), 93-109.

25. Jensen, M. C. 2001. Corporate Budgeting is Broken, Let's Fix It. Harvard Business Review, November, 94-101.

26. Kelly, J., dan Wanna, J. 2004. Crashing Through with Accrual-Output Price Budgeting in Australia Technical Adjustment or A New Way of Doing Business? The American Review of Public Administration, 34 (1), 94-111.

27. Kuswarno, E. 2009. Metodologi Penelitian Komunikasi: Fenomenologi; Konsepsi, Pedoman, dan Contoh Penelitiannya. Widya Padjajaran, Bandung.

28. Lapsley, I., Mussari, R., dan Paulsson, G. 2009. On The Adoption of Accrual Accounting in The Public Sector: A Self-Evident and Problematic Reform. European Accounting Review, 18 (4), 719-723.

29. Lim, F. 2008. Filsafat Teknologi: Don Inde tentang Dunia, Manusia, dan Alat. Penerbit Kanisius, Yogyakarta.

30. Lüder, K. 2000. National Accounting, Governmental Accounting and Cross-country Comparisons of Government Financial Condition. Financial Accountability \& Management, 16 (2), 117-128.

31. Lüder, K. G. 1992. A contingency model of governmental accounting Innovations in the political administrative environment. . Research in Governmental and Nonprofit Accounting, 7, 99-127.

32. Manning, N. 2001. The Legacy of New Public Management in Developing Countries. International Review of Administrative Sciences, 67 (2), 297-312.

33. Mellett, H., Macniven, L., dan Marriott, N. 2007. NHS Resource Accounting in Wales: Problems of Implementation. Institute of Chartered Accountants of Scotland.

34. Mimba, N. S. H., Helden, G. J. V., dan Tillema, S. 2007. Public Sector Performance Measurement in Developing Countries. Journal of Accounting \& Organizational Change, 3 (3), 192-208.

35. Montesinos, V., dan Vela, J. M. 2013. Innovations in Governmental Accounting. Springer Science \& Business Media.

36. Mulford, C. W., dan Comiskey, E. E. 2002. The Financial Numbers Game: Detecting Creative Accounting Practices. John Wiley \& Sons.

37. Otley, D. T. 1980. The Contingency Theory of Management Accounting: Achievement and Prognosis. Accounting, Organizations and Society, 5 (4), 413-428.

38. Paulsson, G. 2006. Accrual Accounting in The Public Sector: Experiences From The Central Government in Sweden. Financial Accountability \& Management, 22 (1), 47-62.

39. Poloma, M. M. 2004. Sosiologi Kontemporer. PT RajaGrafindo, Jakarta.

40. Prodjoharjono, S. 1999. Accrual Accounting in Indonesian Local Government. University of Birmingham.

41. Rezaee, Z. 2002. Financial Statement Fraud: Prevention and Detection. John Wiley \& Sons.

42. Ryan, C. 1999. Australian Public Sector Financial Reporting: A Case of Cooperative Policy Formulation. Accounting, Auditing \& Accountability Journal, 12 (5), 561-582. 
43. Saleh, Z., dan Pendlebury, M. W. 2006. Accruals Accounting in Government Developments in Malaysia. Asia Pacific Business Review, 12 (4), 421-435.

44. Schilit, H. M., dan Perler, J. 2010. Financial Shenanigans: How To Detect Accounting Gimmicks and Fraud in Financial Reports Vol. 3th edition. Howard Schilit

45. Stamatiadis, F., dan Eriotis, N. 2011. Evolution of The Governmental Accounting Reform Implementation in Greek Public Hospitals: Testing The Institutional Framework. Paper presented at the 34th Annual Congress of the European Accounting Association.

46. Triyuwono, I., dan Roekhuddin. 2000. Konsistensi Praktik Sistem Pengendalian Intern dan Akuntabilitas pada Lazis (Studi Kasus di Lazis X Jakarta). Jurnal Riset Akuntansi Indonesia, 3 (2), 151-167.

47. Wynne, A. 2008. Accrual Accounting For the Public Sector - A Fad That Has Had Its Day? International Consortium on Governmental Financial Management, VIII (2), 117132.

48. Yamamoto, K. 2001. Transforming Government Accounting in Japan: Revolution or Fashion? International Comparative Issues in Government Accounting. hlm. 251-263. Springer.

49. Yudi. 2007. Realitas Aktivitas Pengendalian Akuntansi Sektor Publik. Studi Pada Salah Satu Satuan Kerja Pengelola Keuangan Daerah (SKPKD) di Provinsi Jambi. S2, Universitas Brawijaya, Malang. 